\title{
The State of Young Adults' Balance Sheets: Evidence from the Survey of Consumer Finances
}

\author{
Lisa J. Dettling and Joanne W. Hsu
}

\begin{abstract}
The authors investigate recent trends in the financial circumstances of young adults using data from the triennial Survey of Consumer Finances (SCF) from 2001 to 2013. They examine trends in young adults' net worth, break down the composition into specific assets and liabilities, and describe young adults' experiences with credit markets. The analysis focuses on three main comparisons: (i) trends over time (ii) between young adults and older adults and (iii) between young adults in 2013 (members of the "Millennial Generation") and young adults in 1989 (members of "Generation X"). They find that between 2001 and 2013, young adults experienced a decline in net worth, driven largely by declines in asset holdings. The median young adult in 2013 also had lower net worth than the median young adult surveyed in the 1989 SCF. Despite media attention surrounding the Millennial Generation's relatively poor economic outcomes during the Great Recession, young adults in the SCF have fared better on many measures than both current older adults and earlier young adults. Compared with older adults, young adults experienced a relatively modest decline in net worth, particularly during the Great Recession. Young adults in 2013 were also more likely than young adults in 1989 to own homes, stocks, and retirement accounts, and they were less likely to have very high debt payment-to-income ratios than their counterparts in 2001 and 1989 or older adults in 2013. (JEL D14, D91)
\end{abstract}

Federal Reserve Bank of St. Louis Review, Fourth Quarter 2014, 96(4), pp. 305-30.

\footnotetext{
Lisa J. Dettling and Joanne W. Hsu are economists in the Microeconomic Surveys Section at the Board of Governors of the Federal Reserve System. The authors thank Steve Fazzari, John Sabelhaus, Max Schmeiser, and Jeff Thompson for helpful comments and suggestions and Sebastian DevlinFoltz for excellent research assistance.

○ 2014, The Federal Reserve Bank of St. Louis. The views expressed in this article are those of the author(s) and do not necessarily reflect the views of the Federal Reserve System, the Board of Governors, or the regional Federal Reserve Banks. Articles may be reprinted, reproduced, published, distributed, displayed, and transmitted in their entirety if copyright notice, author name(s), and full citation are included. Abstracts, synopses, and other derivative works may be made only with prior written permission of the Federal Reserve Bank of St. Louis.
} 


\section{Dettling and Hsu}

suggests that today's young adults may have accumulated less wealth than their parents had at the same age (Steuerle et al., 2013). However, because they are still in the beginning of the life cycle, today's young adults may be better equipped to weather economic upheaval than older generations, especially in the long run.

In this article, we investigate recent trends in the financial circumstances of young adults. Using individual-level data from household interviews in the triennial Survey of Consumer Finances (SCF) from 2001 to 2013, we examine the net worth of young adults and divide the composition into specific assets and liabilities. In addition, we describe young adults' experiences with credit markets with respect to credit constraints, delinquency, and debt burdens.

Our analysis focuses on three main comparisons. First, we examine trends in young adults' circumstances between 2001 and 2013, a period characterized by large changes in the overall economy. Second, we compare young adults 18 to 31 years of age with older adults 35 to 50 years of age over that period. Finally, we compare young adults in 2013-members of the "Millennial Generation" - with young adults of the same age in the 1989 wave of the SCFmembers of "Generation X".

We find that between 2001 and 2013, net worth fell among young adults, primarily because of declines in asset holdings. We also find that net worth was lower for young adults in 2013 than it was for young adults in 1989. However, despite popular accounts of the Millennial Generation's poor economic outcomes during the Great Recession, young adults in the SCF have fared relatively well on many measures. Between 2001 and 2013, debt holdings excluding education loans declined among young adults, as did credit constraints. Compared with older adults, young adults experienced a relatively modest decline in net worth between 2001 and 2013, particularly during the Great Recession. Compared with young adults in 1989, young adults in 2013 were more likely to own homes, stocks, and retirement accounts. Moreover, young adults in 2013 were less likely to have high debt payment burdens than older adults, young adults in 1989, and young adults in 2001.

Our results are not necessarily at odds with popular accounts of how young adults fared in the Great Recession. Our analysis of SCF data focuses on balance sheets and credit market experiences, rather than labor market outcomes. Moreover, because of the SCF sample design, the sample of young adults studied represents only the population of young adults living independently, not the entire population of young adults. ${ }^{2}$ We conduct comparisons between SCF young adults and the overall population of young adults from other data sources and find that SCF young adults tend to have higher incomes than the overall population. If income is correlated with wealth, this suggests that the financial circumstances of young adults in the SCF could be better than those experienced by the overall population of young adults.

\section{DATA}

We use data from multiple waves of the SCF. ${ }^{3}$ The SCF is a nationally representative survey of households conducted triennially by the Board of Governors of the Federal Reserve System to gather comprehensive information on household assets, liabilities, income, and credit market experiences. The SCF provides a comprehensive look at household balance sheets that 
describes both the ownership and magnitude of particular assets and debt. In addition, the SCF collects demographic information and employment and household income data. Wealth data from the SCF are widely regarded as the most reliable and extensive available in the United States. Our primary analysis focuses on young adults, defined as individuals 18 to 31 years of age, in the 2001, 2004, 2007, 2010, and 2013 waves of the SCF. We also compute some statistics for individuals 35 to 50 years of age during those years (referred to as "middle adults") as well as for young adults from the 1989 wave for comparison.

The SCF is a household survey, and its sampling frame is designed to be representative at the household level. Young adults can be members of very different types of households in the SCF because their living arrangements and family structure vary so widely. A young adult may be living completely independently, with a spouse or cohabitating partner, with roommates, or with a parent. In each case, the SCF might capture different types of information about the individual, and our analysis must be tailored to address these differences. In the SCF, assets and liabilities are collected at the household level and are pooled for all financially dependent household members, called the "primary economic unit." Income data are collected only for household heads and spouses/cohabitating partners. Among roommates, the eldest roommate is typically selected for inclusion in the survey. Unless the roommates consider themselves financially dependent on one another, very little information is collected about the other roommates, who are not considered members of the primary economic unit. Individuals living with their parents may contribute to the total household assets and liabilities, but only if the parent considers the child financially dependent and part of the primary economic unit. ${ }^{4}$

We calculate individual-level versions of the household-level measures of assets, liabilities, and income in the SCF to facilitate comparisons between individuals in different types of living arrangements. In most cases, we calculate this measure by weighting the total measures of income, assets, and debt by $1 / N$, where $N$ is the number of adults (over 18 years of age) in the primary economic unit. There are several important exceptions to this procedure. First, since wage information is collected only for heads and spouses/cohabitating partners, we can calculate income only for those individuals. Second, when a young adult is in the primary economic unit and the household head is a parent or grandparent (or any other adult older than 50 years of age who is not the spouse or/cohabitating partner), we omit that young adult from the analysis and do not assign him or her a share of the household's total assets or liabilities because the household's financial circumstances are likely to be dominated by the head rather than the young adult child/grandchild. In a later section, we further discuss issues about generalizability that arise from the SCF's sampling frame and the young adults not captured because they are not part of the primary economic unit.

The SCF contains information on whether an individual holds various types of assets and debts, as well as the balances associated with such accounts. We use this information to study net worth, total asset holdings, total liabilities, and total holdings of various types of assets and debt. Total assets are an aggregate measure of all holdings in checking accounts, savings/money market accounts, stocks, bonds, quasi-liquid retirement accounts, and any homes or vehicles owned by the family. Total liabilities are similarly measured as the sum of housing debt (including second mortgages and home equity loans), lines of credit, credit cards, installment debt, 


\section{Dettling and Hsu}

vehicle loans, student loans, and other debt. Net worth is defined as the total of all assets net of all debt. ${ }^{5}$

We also separately analyze several broad categories of assets and debt of particular importance to young adults. On the asset side, we summarize bank deposits (checking and savings accounts), housing, quasi-liquid retirement accounts (such as $401(\mathrm{k}) \mathrm{s}$ and individual retirement accounts), and stock holdings. On the debt side, we separately summarize credit card debt, housing debt, vehicle loans, and student loans. Most of our analysis focuses on medians because of skewness in the distributions of financial holdings, although we present information on other aspects of the distributions as well.

The SCF also asks respondents about their interactions with credit markets and their debt burdens in addition to surveying them on aspects of their balance sheet. Collected information includes payment behavior, payment burdens, and bankruptcy filing. We can infer whether the individual is credit constrained based on questions about applications for credit. The survey asks the respondent whether he or she was denied credit in the past two years and whether the individual opted not to apply for credit for fear of being denied. We define individuals who report "yes" to either question as credit-constrained. Finally, we construct several measures of debt burdens, including leverage ratios, debt-to-income ratios, and payment-toincome ratios. We consider payment burdens on loans that are in repayment separately from those in deferment.

\section{TRENDS IN BALANCE SHEETS OF YOUNG ADULTS}

\section{Net Worth}

Figure 1A displays various points in the distribution of net worth for young adults in the SCF from 2001 to 2013, expressed in 2013 dollars. In 2001, the median net worth for young adults was $\$ 8,900$. The median level grew until 2004 and then declined over the next three waves, falling to $\$ 6,100$ in 2013 . At the 75 th percentile, net worth was $\$ 45,400$ in 2001 . This number fell throughout the period; the largest drop occurred between the 2007 and 2010 waves. In 2013 , net worth at the 75 th percentile was $\$ 29,400$. At the 25 th percentile, net worth remained below $\$ 1,000$ throughout the period.

The right side of Figure 1A displays the 25th percentile, median, and 75th percentile of net worth for young adults in 1989. The median young adult in 1989 fared slightly worse than the median young adult in 2001 and 2004 but better than the median young adult from 2007 to 2013. In 2013, the median young adult's net worth was 30 percent lower than median net worth among young adults in 1989. This gap is even larger for young adults in the 75th percentile, who had 60 percent greater net worth in 1989 than young adults in the 75th percentile did in 2013.

Figure 1B displays the ratio of median young adult net worth to middle adult (35 to 50 years of age) net worth. In 2001, median net worth for middle adults was $\$ 77,200$. Between 2001 and 2004, net worth of the median young adult was about 10 percent that of middle adults. This ratio fell slightly between 2004 and 2007 and then rose to 14 percent in 2010, where it 
Dettling and Hsu

\section{Figure 1}

\section{Net Worth Among Young Adults}

\section{A. Distribution of Net Worth}

Total Net Worth (\$ thousands)

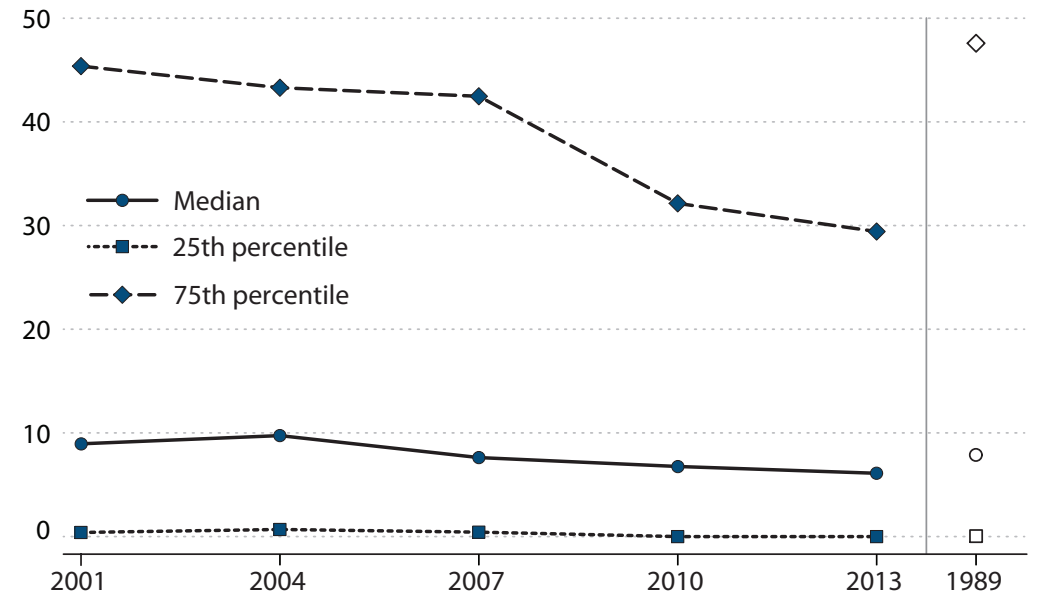

\section{B. Ratio of Young Adult to Middle Adult Median Net Worth}

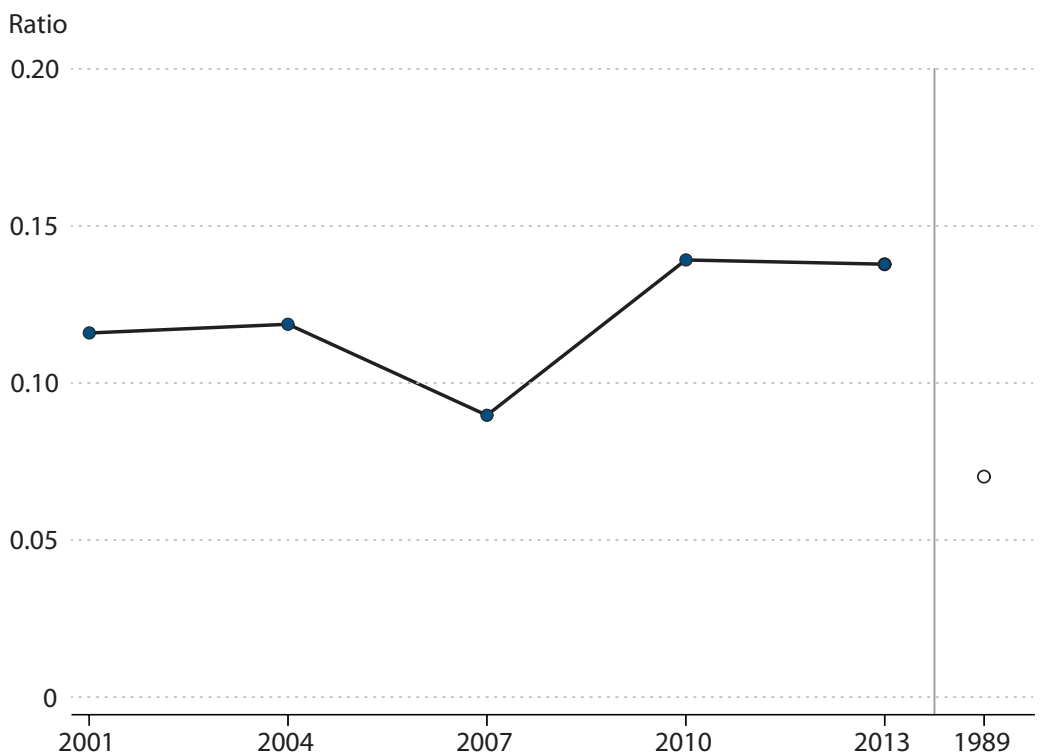

NOTE: Panel A shows various points in the distribution of net worth among young adults 18 to 31 years of age. Panel B shows the ratio of the net worth of middle adults ( 35 to 50 years of age) to the median net worth of young adults (18 to 31 years of age). All nominal values were adjusted to 2013 dollars using the Consumer Price Index for All Urban Consumers (CPI-U).

SOURCE: SCF. 


\section{Dettling and Hsu}

\section{Figure 2}

\section{Distribution of Assets and Debt Among Young Adults}

\section{A. Assets}

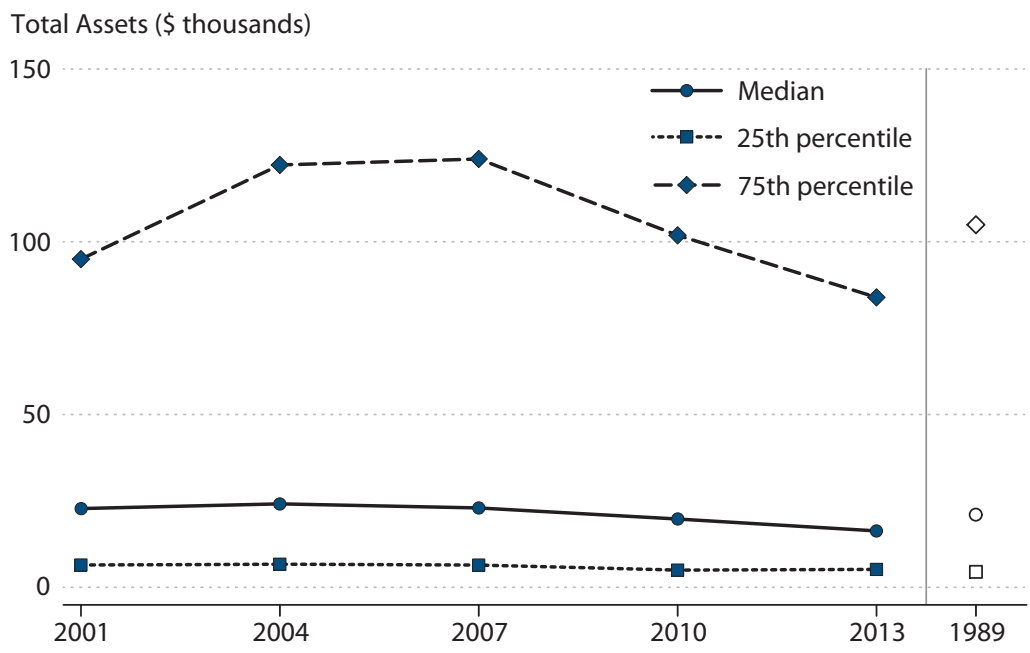

\section{B. Debt}

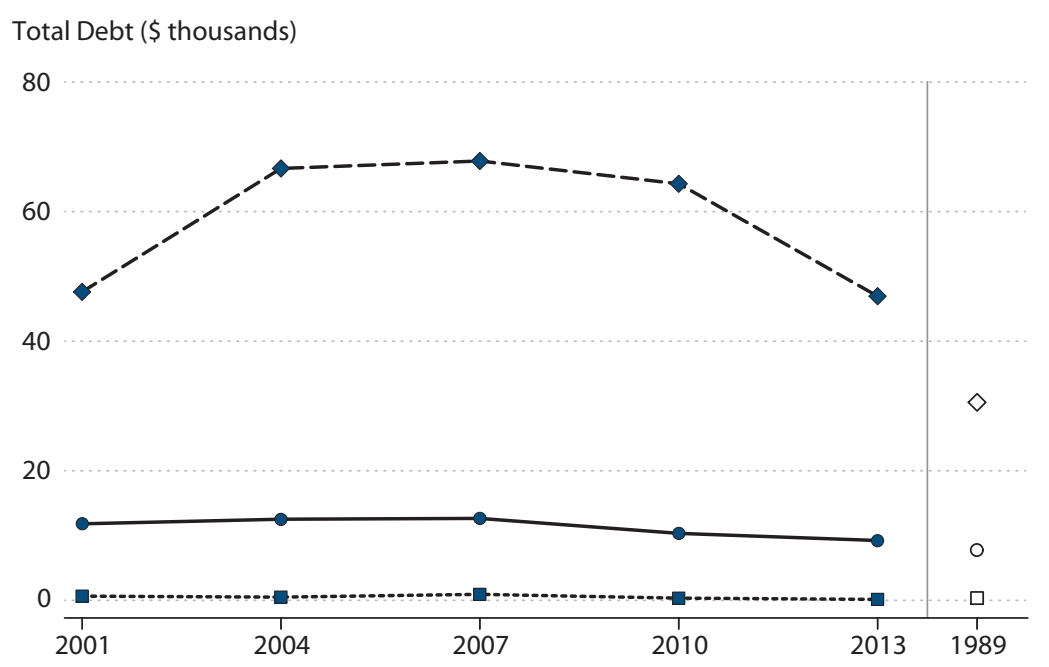

NOTE: The figure shows various points in the distribution of total assets (Panel A) and total debt (Panel B) among young adults 18 to 31 years of age. All nominal values were adjusted to 2013 dollars using the CPI-U.

SOURCE: SCF. 
remained through 2013. These trends are probably attributable to the fact that young adults are less likely to own homes or stocks than other age groups. They therefore did not benefit as much from the housing and stock market boom between 2004 and 2007, nor did they suffer as much from the housing and stock market bust from 2007 to 2010. The right side of Figure 1B shows that young adults in 2013 had higher net worth relative to contemporaneous middle adults than young adults in 1989 had relative to their middle-adult peers.

Figure 2 breaks down the observed trends in net worth into trends in total accumulated assets and debt at various points in the distribution. Figure 2A displays the 25 th percentile, median, and 75th percentile for total asset holdings. Median total assets hovered between $\$ 22,000$ and $\$ 24,000$ through the early 2000 s, dropping to $\$ 16,300$ by 2013 . Similar trends emerge at both the 25th and 75th percentiles. Figure 2B displays trends in debt holding. Median total debt among young adults was close to $\$ 12,300$ throughout the period from 2001 to 2007, declining to $\$ 9,200$ by 2013 . Again, a similar time trend emerges at the 25 th and 75 th percentiles of debt holding. Relative to young adults in 1989, the median young adult in 2013 held fewer assets and more debt. At the 75th percentile, young adults in 2013 held 54 percent more debt and 20 percent fewer assets than their counterparts in 1989.

The panels in Figure 3 display trends in net worth, total assets, and total debt for young adults by level of education, defined as the highest level of schooling completed. Individuals are grouped into four education categories: high school dropouts, high school graduates, those with some college, and those with a bachelor's degree or more. The patterns are similar to those in Figures 1 and 2. Although net worth remained substantially higher among college-educated individuals than among less-educated individuals throughout the period, it did fall substantially. Figures $3 \mathrm{~B}$ and $3 \mathrm{C}$ show that the decline in net worth for college-educated individuals was driven by a large increase in total debt between 2001 and 2010 and a decline in assets between 2010 and 2013. The right side of Figure 3 shows that college-educated young adults in 2013 had higher debt burdens, lower total asset holdings, and lower net worth than their counterparts had in 1989. For those with a high school diploma or some college, net worth rose slightly between 2001 and 2004 and then fell through 2013. For high school dropouts, median net worth was $\$ 2,500$ in 2001 and grew to $\$ 4,700$ in 2013 , nearly converging with the net worth of high school graduates and those with some college. Compared with 1989, young adults in 2013 with at least some college had much lower net worth. The net worth of those with a high school diploma was similar to that of their counterparts in the 1989 survey, and net worth for high school dropouts was lower for young adults in 1989 than in 2013.

\section{Assets}

Figure 4 displays ownership patterns and conditional median values of the four main categories of assets: bank deposits, housing, retirement accounts, and stocks. The blue bars show the fraction of young adults with each asset type, and the black dots and dashed lines mark the conditional median value of each asset type. In 2013, over 97 percent of young adults owned some type of asset; 90 percent had a deposit account, 34 percent owned a home, 37 percent had a retirement account, and 37 percent owned stocks. ${ }^{6}$ In general, asset ownership rates fell between 2001 and 2013. 


\section{Dettling and Hsu}

\section{Figure 3}

\section{Net Worth, Assets, and Debt Among Young Adults by Education}

\section{A. Net Worth}

Net Worth ( $\$$ thousands)

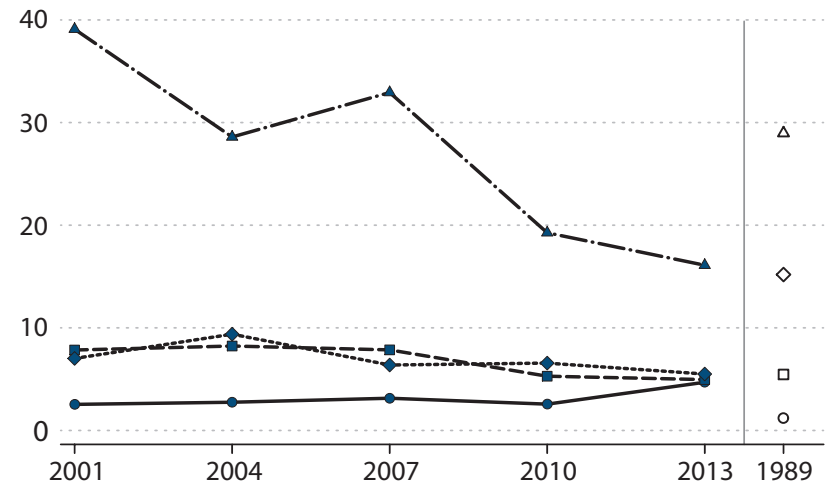

\section{Total Debt}

Median Total Debt ( $\$$ thousands)

80

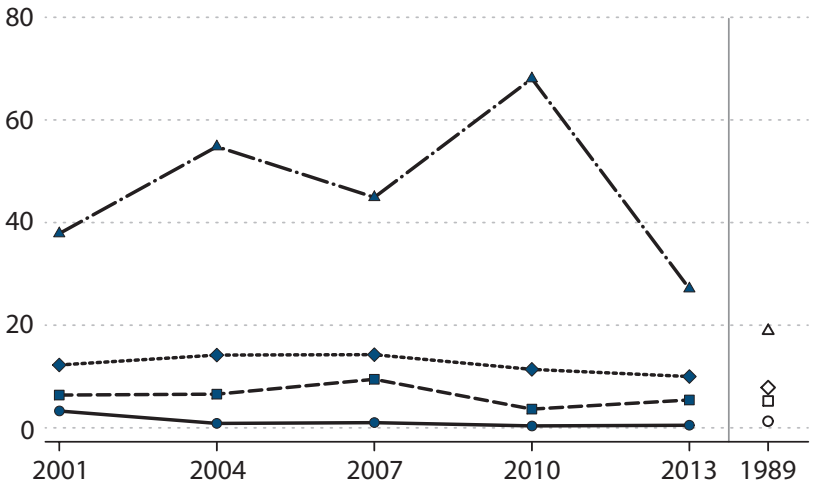

B. Total Assets

Median Total Assets (\$ thousands)

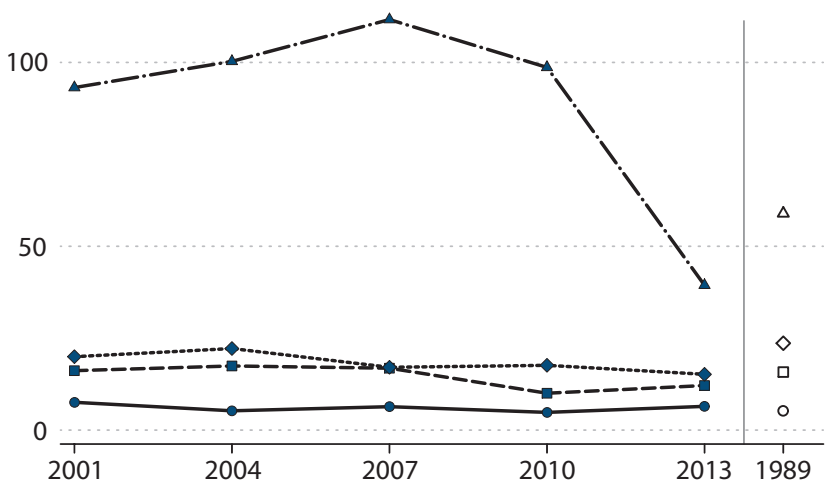

NOTE: The figure shows trends in net worth (Panel A), total assets (Panel B), and total debt (Panel C) among young adults 18 to 31 years of age by level of education. All nominal values were adjusted to 2013 dollars using the CPI-U.

SOURCE: SCF. 
Figure 4A shows that about 87 percent of young adults had bank deposits (checking accounts, savings accounts, or both) in 2001; this proportion rose slightly to 90 percent by 2013. The fractions of young adults with bank deposits were very similar to the fraction of middle adults with bank deposits over that period. The conditional median value of bank deposits also remained fairly stable throughout the period, ranging between $\$ 1,500$ and $\$ 1,800$. Relative to young adults in 1989, young adults in 2013 were 10 percentage points more likely to have bank deposits, but the conditional median value of those bank deposits was similar to the value observed in 1989. Figure 5A displays trends in conditional values for the 25 th and 75th percentiles of the distribution as well as the median. This figure shows that bank deposits rose substantially at the 75 th percentile until 2010 . Figure $5 \mathrm{~A}$ also indicates that the conditional value of bank deposits at the 75th percentile for young adults in 2013 was considerably higher than for young adults in 1989.

Figure 4B displays the homeownership rates and conditional median values of housing assets. In both 2001 and 2004, 39 percent of young adults reported owning homes, but by 2013 the homeownership rate for young adults had fallen to 34 percent. Throughout the period, however, the homeownership rate of young adults remained about half that of middle adults, whose rate of ownership was 72 percent in 2001 and 66 percent in 2013. The conditional median value of housing assets closely followed the path of home prices over the same period, rising from 2001 to 2007 and falling from 2007 to 2013. Figure 5B shows that this trend in housing asset values is also observed at the 75th and 25th percentiles. Relative to young adults in 1989, young adults in 2013 were more likely to own a home, but conditional on ownership, the value of the median young adult's home was lower in 2013. In fact, the conditional median value of homes owned by young adults in 1989 was approximately equal to the conditional median value of homes owned by young adults in 2007, the peak of the housing boom (as captured in the triennial SCF). Moreover, Figure 5B shows that relative to 1989, the distribution of home values was more concentrated in 2013: Values for young adults in 1989 were lower at the 25th percentile and higher at the 75th percentile. Moreover, the value of a home owned by the median young adult in 1989 was 75 percent that of the value of a home owned by a median middle adult that same year, while the ratio was 71 percent for young adults in 2013.

Figure 4C displays trends in ownership of quasi-liquid retirement accounts, which include individual retirement accounts and account-type plans such as $401(\mathrm{k}) \mathrm{s}$. (Note that this does not include the present value of defined benefit retirement plans). Between 2001 and 2013, the share of young adults with retirement accounts remained near 40 percent. Time trends in ownership were similar for middle adults, but their ownership rates were higher, approximately 60 percent, throughout the period shown. In 2013, conditional on owning a retirement account, the median young adult held $\$ 6,500$ in such accounts. Figure $5 \mathrm{C}$ displays the 75 th and 25 th percentile values; in 2013; those in the 75th percentile had approximately $\$ 17,000$ in retirement accounts, while those in the 25 th percentile had approximately $\$ 1,500$. Time trends indicate that the value of these accounts fluctuated throughout the period at all points in the distribution, but the conditional values of these accounts are difficult to interpret because they can be attributed to changes in both the stock market and contributory behavior. Relative to young adults in 1989, young adults in 2013 were much more likely to have quasi-liquid retirement 


\section{Dettling and Hsu}

\section{Figure 4}

\section{Ownership Rates and Median Asset Values Among Young Adults}

\section{A. Bank Deposits}

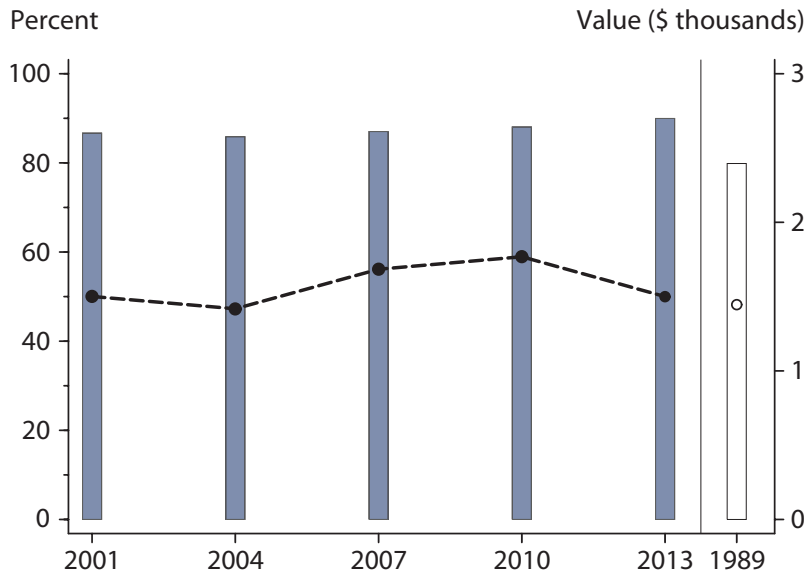

\section{Retirement Accounts}

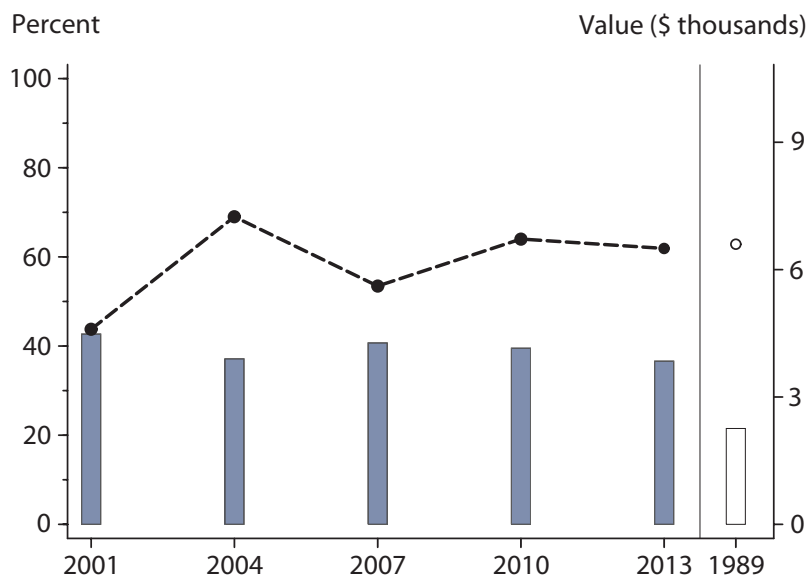

\section{B. Housing}

Percent Value (\$ thousands)

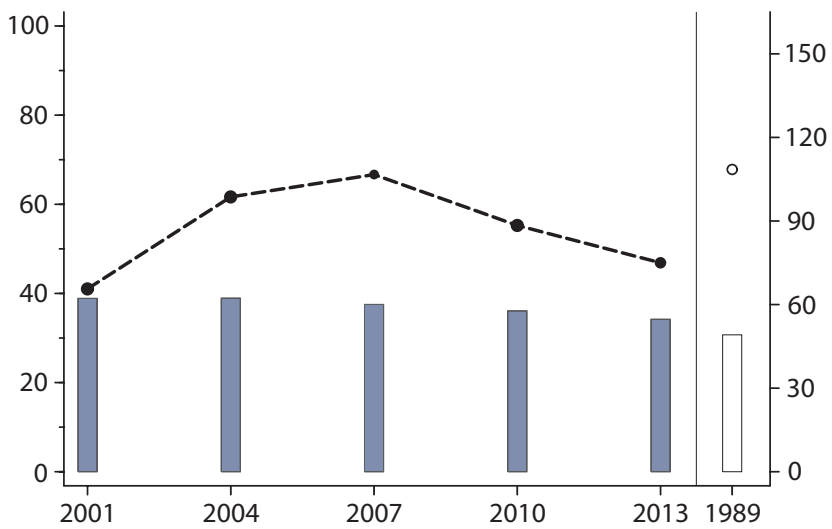

\section{Stocks}
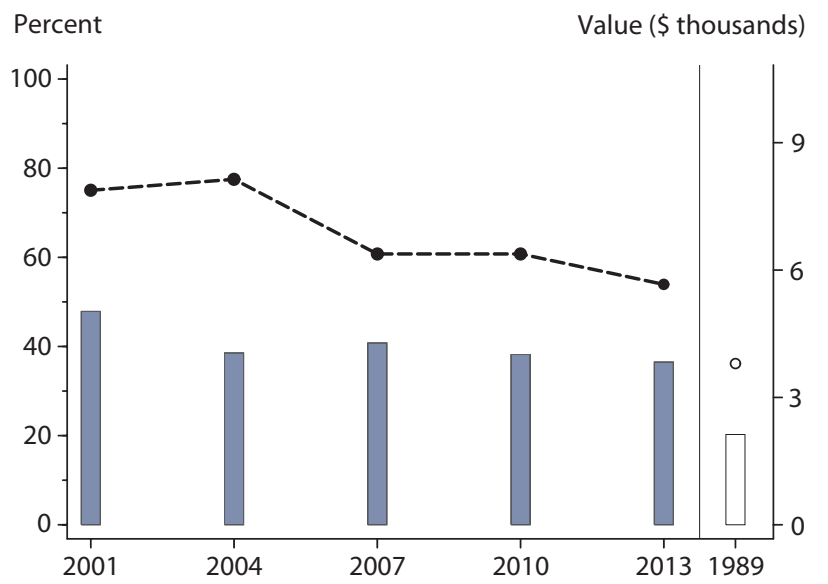

- Conditional Median Value

NOTE: The figure shows the asset ownership rates and conditional median values for different asset types among young adults 18 to 31 years of age. All nominal values were adjusted to 2013 dollars using the CPI-U.

SOURCE: SCF. 


\section{Figure 5}

\section{Distribution of Asset Values Among Young Adults}
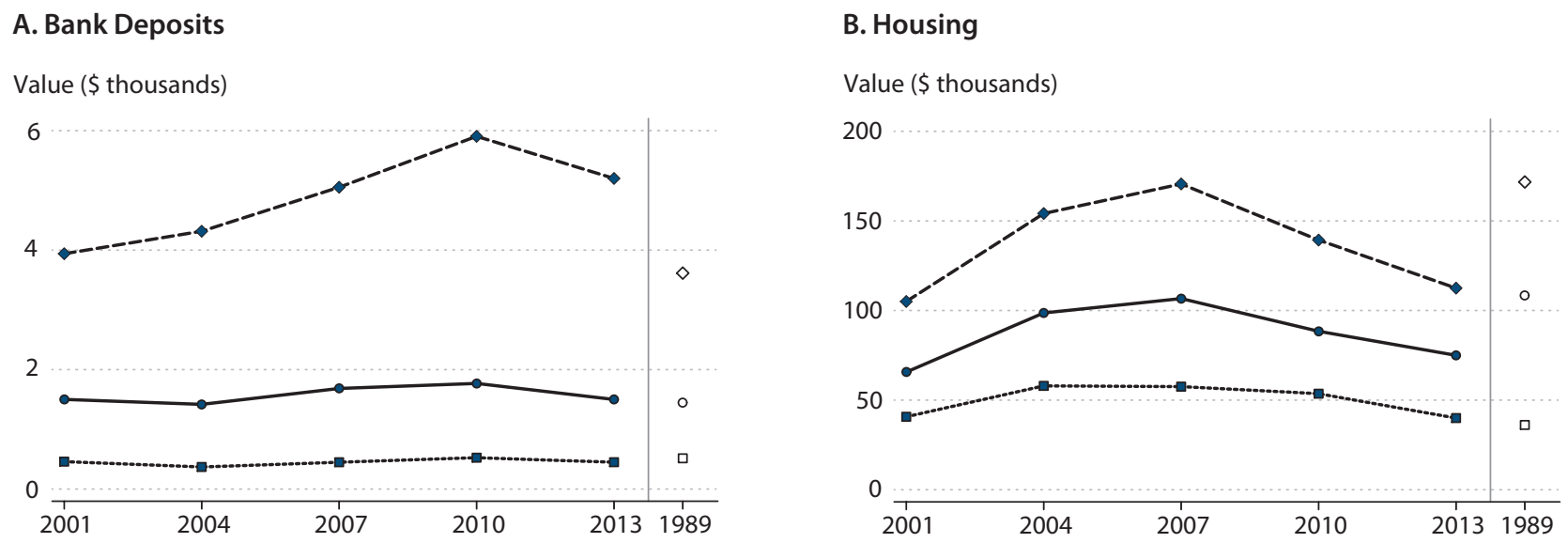

\section{Retirement Accounts}

\section{Stocks}

\section{Value ( $\$$ thousands)}

20

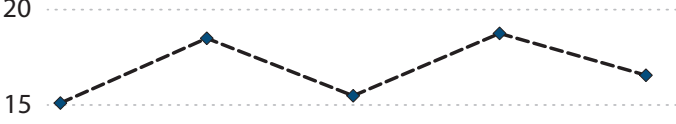

10

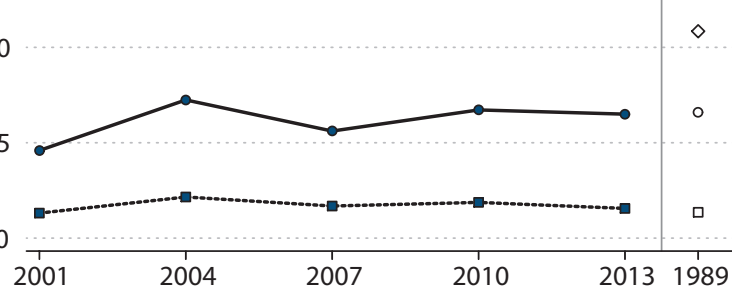

Value ( $\$$ thousands)

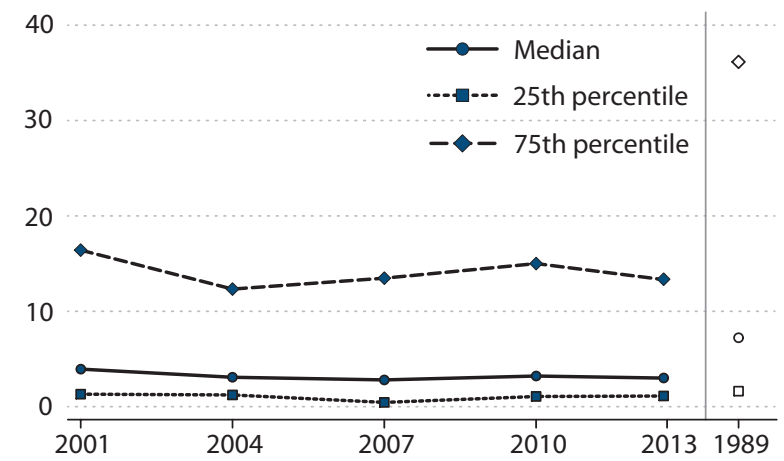

NOTE: The figure shows the distribution of total values for different asset types among young adults 18 to 31 years of age. All nominal values were adjusted to 2013 dollars using the CPI-U.

SOURCE: SCF. 


\section{Dettling and Hsu}

accounts, although conditional on ownership, the values of these accounts were similar at both the median and 25 th percentile. The conditional value at the 75 th percentile, however, was much higher in 2013 than in 1989. These trends in ownership and conditional values of retirement accounts are probably at least partially attributable to the declining prevalence of defined benefit pensions since the 1980s and the increasing prevalence of account-type plans as an alternative. ${ }^{7}$

Lastly, Figure 4D displays trends in stock ownership. The definition of stock ownership used here is broad and includes stocks in publicly traded companies held both directly and indirectly (such as those in retirement accounts or pooled investment funds). The share of young adults who owned stocks declined throughout the period: from 48 percent in 2001 to 37 percent in 2013. Rates of stock ownership among middle adults also fell over this period, although by relatively less than among young adults: from 60 percent in 2001 to 56 percent in 2013. The conditional median value of stocks owned by young adults also fell throughout the period, from $\$ 7,900$ in 2001 to $\$ 5,600$ in 2013 . Again, this decline is difficult to interpret as it may reflect changes in the stock market or the composition of stock owners if those who continued to hold stocks invested less money in them or held stocks of relatively lower values. Both stock ownership and conditional median values of stocks have been higher among young adults in 2013 than among their 1989 counterparts. Figure 5D shows that the downward trends in the conditional median value of stocks over this period occurred at the 25 th percentile, median, and 75th percentile alike.

The evidence in this section indicates that asset holding was relatively stable among young adults throughout the period studied, although bank deposits grew slightly and ownership of homes, retirement accounts, and stock fell between 2007 and 2013. This pattern partially reflects a general retreat toward safer assets during this period, since ownership rates of stock fell and ownership rates of bank deposits rose for middle adults as well. Indeed, SCF data show that young adults have reported increased unwillingness to bear risk in financial investments since 2001. Compared with young adults in 1989, young adults in 2013 were more likely to own all types of assets studied here, including bank deposits, homes, retirement accounts, and stocks.

\section{Debt}

Figure 6 displays ownership patterns and conditional median values for four types of debt: credit card debt, housing debt, automobile loans, and student loans. The blue bars show the fraction of young adults with each type of debt; the black dots and dashed lines represent the conditional median value of the debt. While about 80 percent of young adults in the sample period had some sort of debt, rates varied quite dramatically across the different types of debt. Across the five most recent waves of the survey, about 43 percent of young adults had credit card debt, 39 percent had auto loans, 33 percent had mortgages, and 34 percent had student loans. Generally, rates of holding the various types of debt did not change substantially between 2001 and 2007 but fell between 2007 and 2013. Conditional on holding debt, balances also generally fell between 2007 and 2013. In both trends, student loans are an exception, as discussed below. 
Figure 6A displays trends in credit card debt, which is defined as the outstanding balance after the most recent payment and includes bank-issued credit cards and retail cards. ${ }^{8}$ Between 2001 and 2013, the incidence of credit card debt generally fell, as did the conditional median value of the debt. In 2013, 36 percent of young adults had credit card debt compared with 43 percent of middle adults. The median credit card borrower owed slightly more than $\$ 1,000$ throughout the sample period, although there was a slight downward trend in the median value. Figure 7A shows this slight downward trend in the value of credit card debt at both the median and 25th percentile, but not the 75th percentile, where the value of credit card debt increased until 2007 before falling. Compared with young adults in 1989, young adults in 2013 were less likely to hold credit card debt and held less debt at each point in the distribution.

Figure 6B displays trends in housing debt, which includes mortgages, home equity loans, and home equity lines of credit on both principal residences and other real estate properties. Between 2001 and 2013, the fraction of young adults with housing debt fell from 35 percent to 27 percent. Housing debt ownership for middle adults also fell over this period, from a peak of 66 percent in 2004 to 58 percent in 2013. The conditional median value of housing debt was $\$ 61,200$ for young adults in 2013 , below the median of $\$ 80,000$ for middle adults. The conditional median debt values for young adults essentially followed the path of home prices over the period, which is consistent with the fact that young adults tend to hold recently opened loans. Figure 7B shows that trends in the value of debt holdings were similar across the distribution. In 2013, housing debt for those at the 75 th percentile was $\$ 100,000$, compared with $\$ 38,300$ for those at the 25 th percentile. Young adults held housing debt at similar rates in 2013 and in 1989, but the conditional median value of debt for young adults in 2013 was about 20 percent lower than it was in 1989.

Figure 6C displays trends in automobile debt, which consists of installment loans for both new and used vehicles. The fraction of young adults with automobile debt fell from 45 percent in 2001 to 35 percent in $2013 .^{9}$ As a comparison, 38 percent of middle adults had auto debt in 2013. The median young adult with auto debt in 2013 owed approximately $\$ 6,500$, which is similar to the median $\$ 7,000$ owed by middle adults. Figure $7 \mathrm{C}$ shows similar trends in conditional values for those in the 25th percentile, median, and 75th percentile group: Auto debt levels rose until 2007 and then fell between 2007 and 2010. Both ownership of auto debt and the conditional median value of the debt were higher in 1989 than in 2013.

Figure 6D displays trends in education debt, which differ from trends for other types of debt. Student loan holding rates and the distribution of values rose substantially throughout the period. In 2001, 26 percent of young adults had a student loan; in 2010 and 2013, 40 percent had a student loan. These numbers are substantially higher for young adults than for middle adults, of whom only 25 percent had student loan debt in 2013. Young adult student loan borrowers owed a median of $\$ 6,600$ in 2001 ; this amount increased continuously between each SCF wave to $\$ 10,100$ in 2007. Median balances fell slightly between 2007 and 2010 and then increased to a new high of $\$ 11,100$ in 2013. Figure 7D indicates that the growth in the value of student loan debt over the period was even stronger at the 75th percentile, where balances grew from $\$ 14,400$ in 2001 to $\$ 24,200$ in 2013 . Balances at the 25 th percentile also grew throughout the analysis period, from $\$ 2,600$ in 2001 to a peak of \$4,600 in 2013. 


\section{Dettling and Hsu}

\section{Figure 6}

\section{Rates of Debt Holding and Median Values of Debt Among Young Adults}

\section{A. Credit Card Debt}

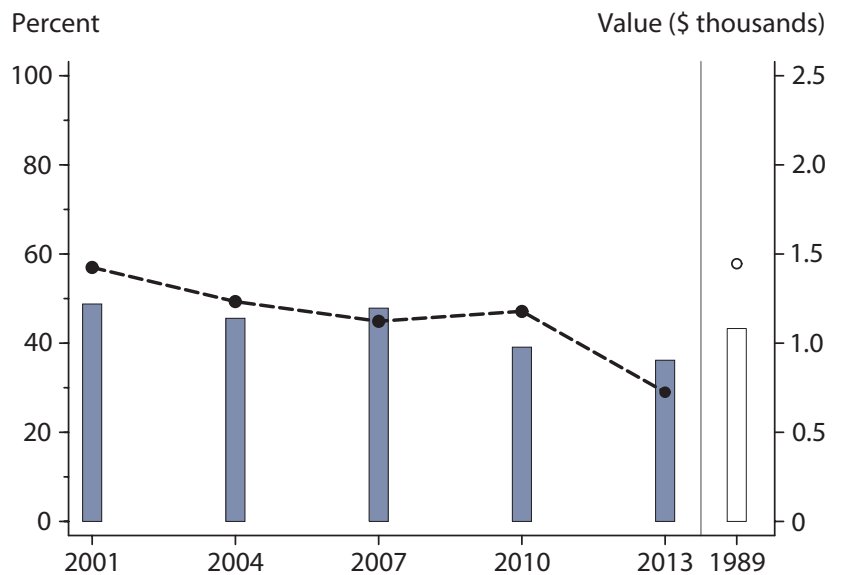

\section{Auto Loans}

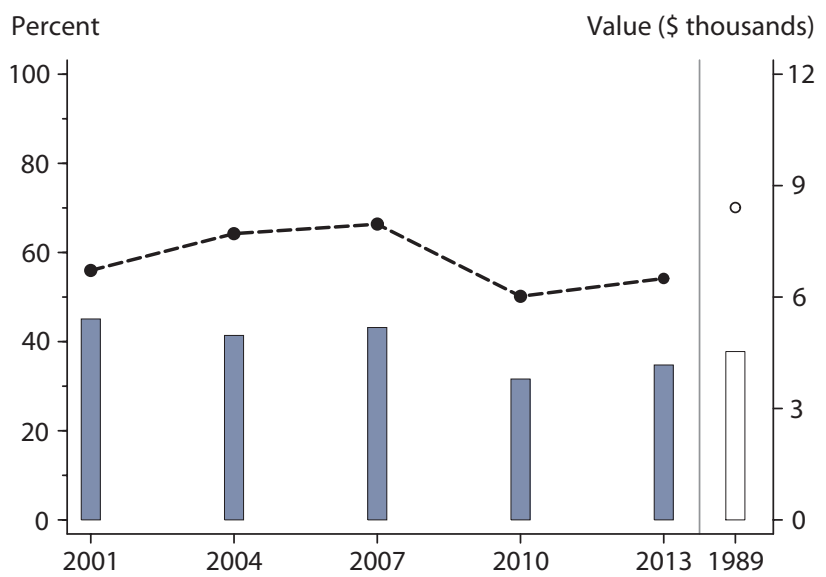

\section{B. Housing}

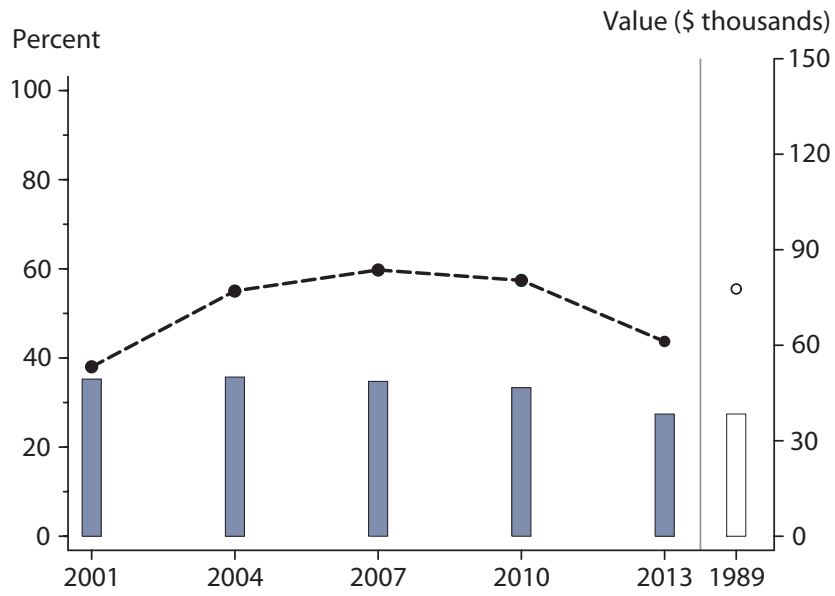

\section{Student Loans}

Percent Value ( $\$$ thousands)

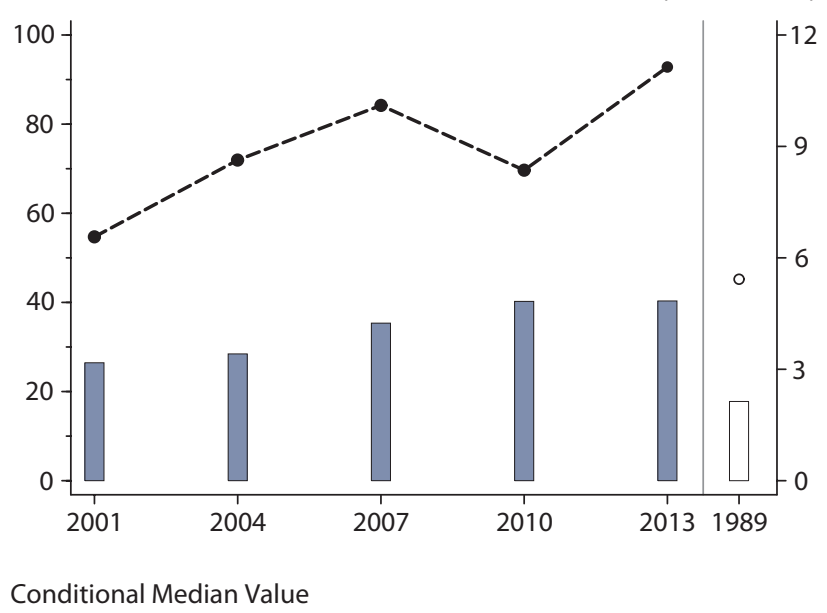

NOTE: The figure shows the rates of debt holding and conditional median values for different types of debt among young adults 18 to 31 years of age. All nominal values were adjusted to 2013 dollars using the CPI-U.

SOURCE: SCF. 


\section{Figure 7}

\section{Distribution of Debt Values Among Young Adults}

\section{A. Credit Card Debt}

Value ( $\$$ thousands)

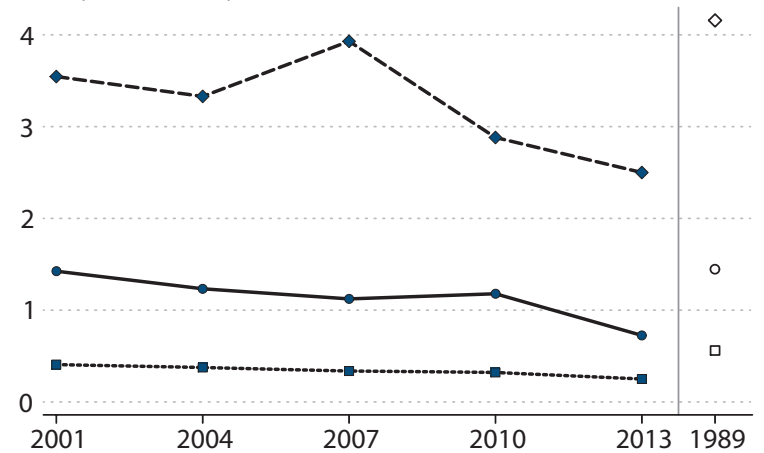

\section{Auto Loans}

Value ( $\$$ thousands)

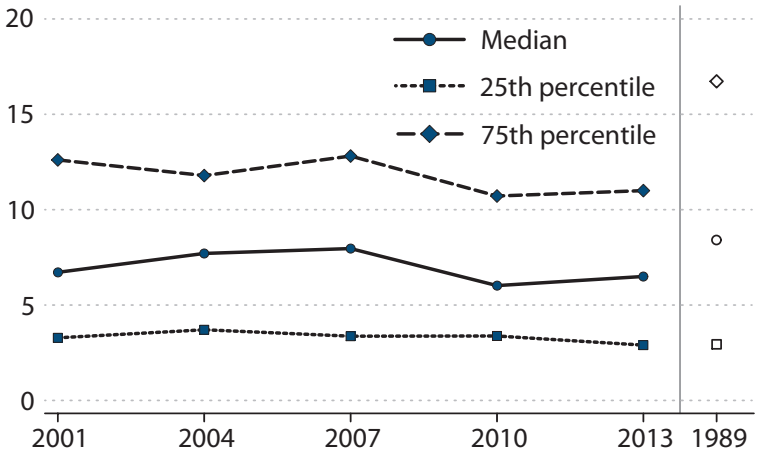

\section{B. Housing}

Value (\$ thousands)

150

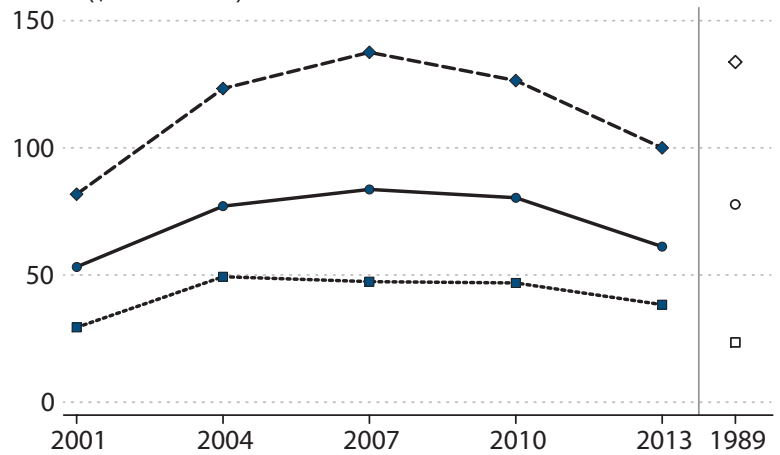

NOTE: The figure shows the distribution of debt values for different types of debt among young adults 18 to 31 years of age. All nominal values were adjusted to 2013 dollars using the CPI-U.

SOURCE: SCF. 


\section{Dettling and Hsu}

Compared with young adults in 1989, young adults in 2013 were more than twice as likely to hold student loan debt and owed more money on student loans. Loan balances at the 25th percentile, median, and 75th percentile were all more than twice as high in 2013 as in 1989.

On net, the evidence in this section indicates that, with the exception of student loans, liabilities have generally declined or remained relatively stable for young adults between 2001 and 2013. ${ }^{10}$ Student loan debt, on the other hand, has risen substantially. Middle adults experienced similar trends in debt holding rates, although they are more likely to hold housing, auto, and credit card debt but less likely to hold student loan debt. Total debt was no higher in 2013 than in 2001. Overall, this suggests that the different types of debt may be substitutes for one another for young adults. Compared with young adults in 1989, young adults in 2013 were much more likely to have student loans, equally likely to hold housing debt, and less likely to carry credit card or auto debt.

\section{Credit Market Experiences}

Next, we examine how young adults interact with credit markets. Figure 8 displays trends among young and middle adults in their experiences with credit markets, as measured by the incidence of reporting credit constraints, use of revolving credit card debt, and missed payments. In the subsequent analysis, we include all respondents regardless of whether they hold debt to assess the overall incidence of particular credit experiences.

Figure 8A shows the fraction of young adults (dark blue bars) and middle adults (light blue bars) who report being credit constrained. As described earlier, we define an individual as credit constrained if he or she reports either being denied credit or not applying for credit for fear of being denied. Figure 8A shows that young adults were decreasingly likely to be credit constrained over the period studied, while middle adults were increasingly likely to be credit constrained. In 2001, 44 percent of young adults reported being credit constrained compared with 28 percent of middle adults. By 2013, this gap had narrowed substantially; 40 percent of young adults and 34 percent of middle adults reported being credit constrained. These declines in the relative incidence of credit constraints occurred despite the passage of the Credit Card Accountability Responsibility and Disclosure Act of 2009 (Credit CARD Act), which took effect before the interview period for the 2010 wave of the survey and differentially tightened lending standards for young adults. The Act made it very difficult for borrowers younger than 21 years of age to acquire credit cards without a cosigner or evidence of sufficient income (Debbaut, Ghent, and Kudlyak, 2013). Compared with young adults in 1989, young adults in 2013 were slightly less likely to report credit constraints.

Figure $8 \mathrm{~B}$ shows the proportion of respondents who have revolving credit card debt, which is defined as carrying a balance month to month by not paying balances in full each month. Between 2001 and 2013, a declining share of young adults had revolving credit card debt: 39 percent in 2001 and 25 percent in 2013. In all years, the share of young adults with revolving credit card debt was less than the share of middle adults. Of note, the sample here includes respondents with no credit cards, and a rising proportion of young adults over this period reported having no credit cards. 
Figures $8 \mathrm{C}$ and $8 \mathrm{D}$ show the fraction of young adults who reported late payments in the 12 months before the survey. As Figure 8C shows, the fraction of young adults with late payments rose from 21 percent in 2001 to 29 percent in 2007 and then fell back to 21 percent in 2013 (this includes both borrowers and respondents who do not currently hold debt). Generally, fewer middle adults than young adults had late payments during the sample period. However, for middle adults, late payment behavior trended upward and by 2010 middle adults and young adults were almost equally likely to report being late on payments. Note that the late payments measure takes a value of 1 even if the respondent missed only one payment. Figure 8D shows a stronger measure of payment delinquency-the fraction of respondents who were ever two or more months late on payments. Between 2001 and 2013, about 9 percent of young adults reported ever being two months late on payments. A smaller proportion of middle adults were late on payments by two months or more between 2001 and 2007, but missed payment behavior in this group spiked and exceeded that of young adults in 2010 before dropping to just below that of young adults by 2013. Compared with young adults in 2001 and 1989, young adults in 2013 were slightly more likely to report being two months or more late on payments.

Our next exercise examines levels of debt burdens, as measured by debt-to-income ratios, leverage ratios, and payment-to-income ratios. Figure 9 displays various measures of debt burden for young adults and middle adults from 2001 to 2013, as well as 1989. In Figures 9A, 9B, and 9C, the dark blue bars refer to young adults 18 to 31 years of age in each survey year, and the light blue bars refer to middle adults 35 to 50 years of age in each survey year.

As shown in Figure 9A, median debt-to-income ratios, defined as the ratio of total income to total debt for those holding debt, were lower for young adults than middle adults in all survey years shown. Debt-to-income ratios have generally increased over time, although they declined slightly for both young and middle adults between 2010 and 2013. The right side of Figure 9A shows that the median young adult in 2013 faced a debt-to-income ratio more than twice as high as that experienced by the median young adult in 1989. Figure 9B shows that the median leverage ratio-the ratio of total debt to total assets-exhibited similar patterns.

While these measures of debt burden for the median debtor provide information on the experiences of the typical young adult, they may fail to capture specific information about debt burdens that ultimately lead to financial stress since such stress may occur only for a small fraction of young adults and not necessarily the typical young adult. We focus on particularly high payment burdens to analyze the incidence of potentially problematic debt among young adults. Figure 9C displays the fraction of respondents with high payment-to-income ratios, defined as total monthly debt repayment obligations totaling more than 40 percent of total monthly income. In 2001, 8.5 percent of young adults had high payment-to-income ratios compared with 10.1 percent of middle adults. The fraction of young adults with high paymentto-income ratios rose substantially between 2001 and 2007, fell back to 2001 levels by 2010, and continued to decline through 2013. In contrast, the fraction of middle adults with high payment-to-income ratios continued to rise between 2007 and 2010 before decreasing substantially between 2010 and 2013. Compared with young adults in 1989, young adults in 2013 were much less likely to have high payment-to-income ratios. In fact, young adults in 1989 were more likely to have high payment-to-income ratios than middle adults in 1989, while in 


\section{Dettling and Hsu}

\section{Figure 8}

\section{Credit Market Experiences Among Young and Middle Adults}

\section{A. Credit Card Constraints}

Percent Reporting Credit Constraints

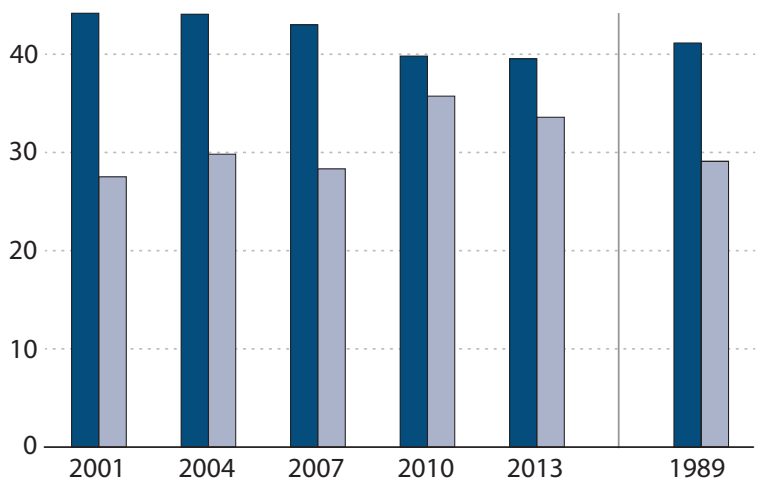

\section{Late on Payments}

Percent Reporting Late Payments

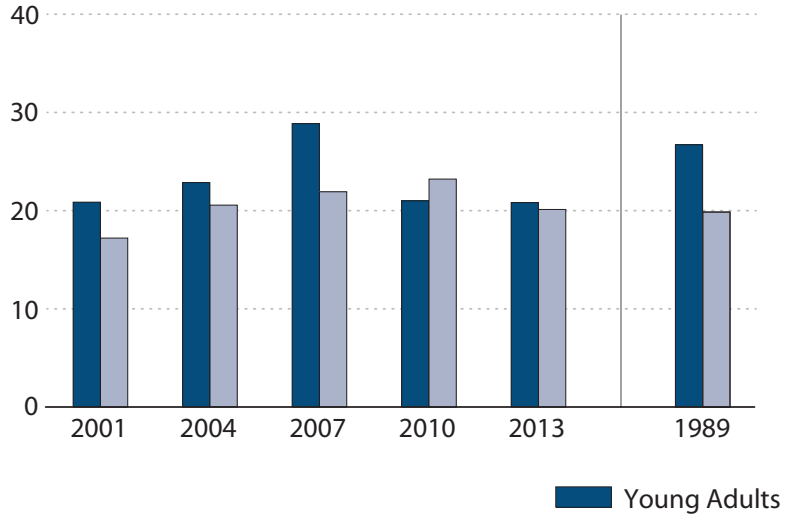

B. Revolving Debt on Credit Card

Percent with Revolving Debt

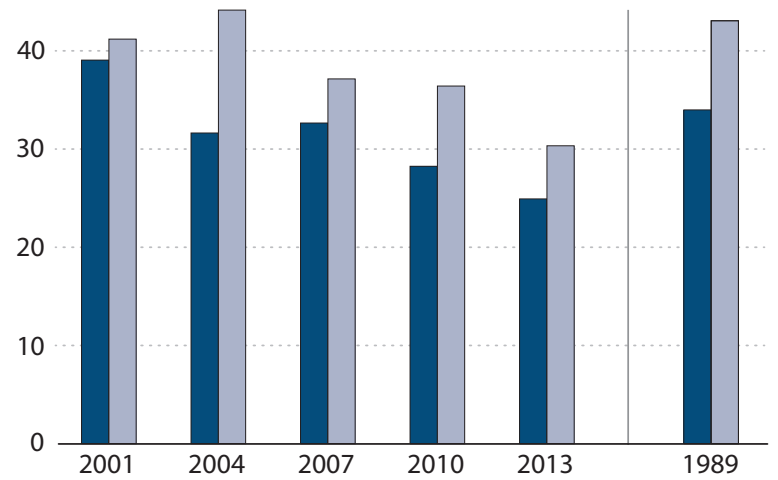

\section{Late on Payments Two Months}

Percent Reporting Very Late Payments

40

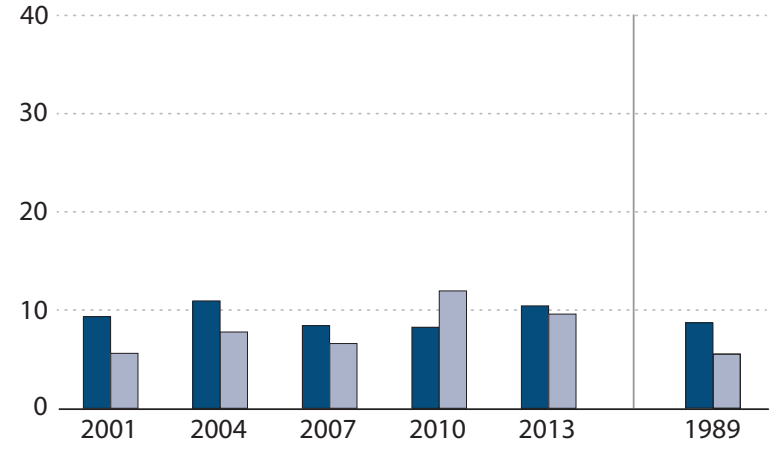

Middle Adults

NOTE: Panel A shows the fraction of young (18 to 31 years of age) and middle ( 35 to 50 years of age) adults with credit constraints. An individual is considered credit constrained if he or she reports either being denied credit in the past two years or not applying for credit for fear of being denied in the past two years. Panel B shows the fraction of young and middle adults who report that they sometimes or hardly ever pay the total balances owed on credit cards each month. Panel D shows the fraction who report being late on payments in the past year, and Panel D shows the fraction who have been late on payments for two or more months.

SOURCE: SCF. 


\section{Figure 9}

\section{Debt Burdens}

\section{A. Median Debt-to-Income Ratio for Debtors}

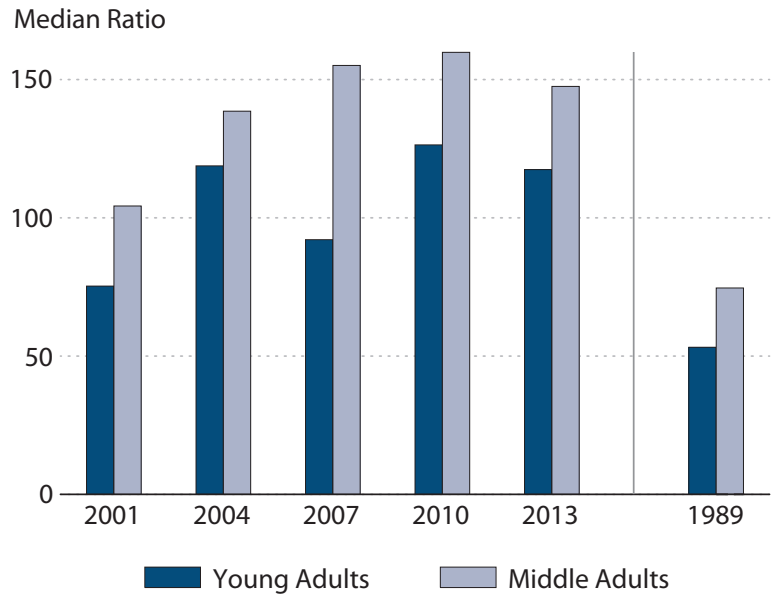

\section{Percent with Payment-to-Income Ratio >40 Percent}

Percent

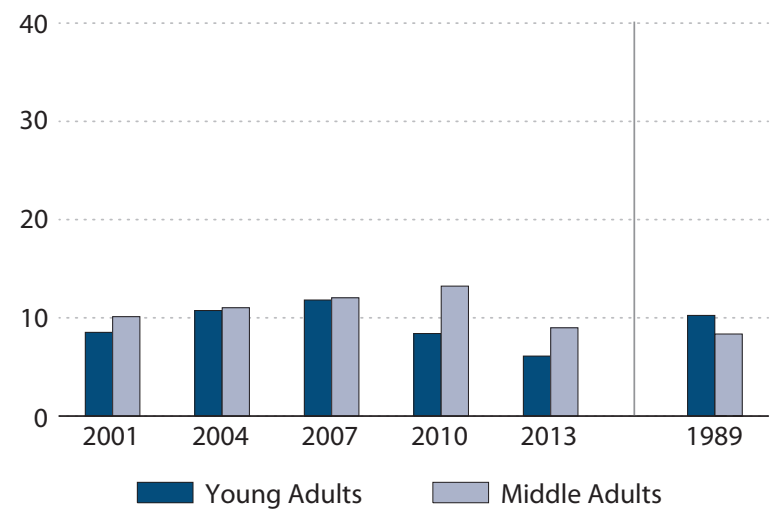

\section{B. Median Leverage Ratio for Debtors}

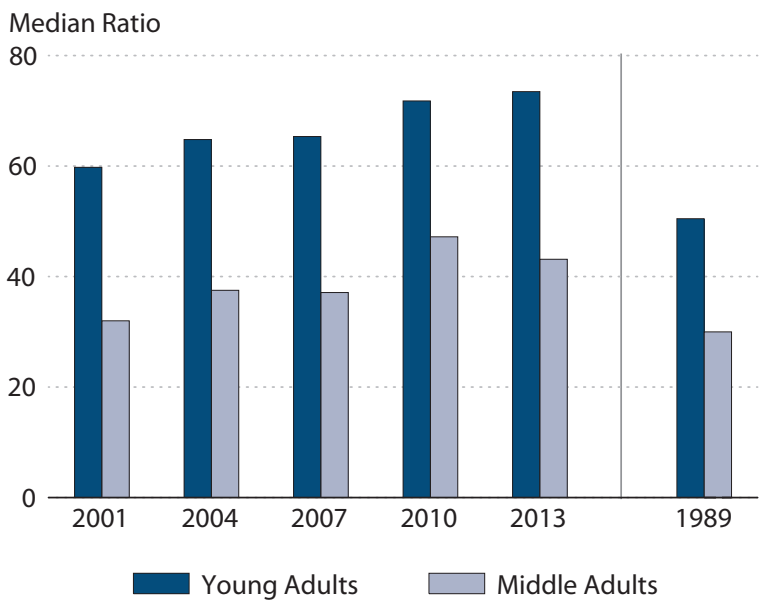

D. Average Payment-to-Average Income Ratios by Type of Debt

Percent

30

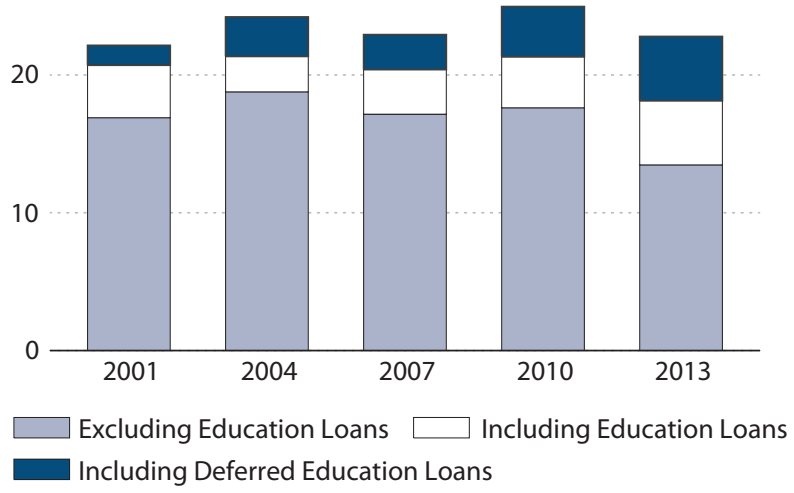

NOTE: Panel A shows the median debt-to-income ratio among young (18 to 31 years of age) and middle ( 35 to 50 years of age) adults. Panel B shows the median leverage ratio among young and middle adults. Panel $\mathrm{C}$ shows the fraction of young and middle adults with payment-to-income ratios greater than 40 percent. Panel D shows the average monthly debt payment-to-average monthly income ratio. Information for student loan deferment status was not collected in 1989, so that year is not displayed in the figure. Debt categories are divided into student loan debt under repayment, student loan debt under deferment, and all other debt.

SOURCE: SCF. 


\section{Dettling and Hsu}

the 2000s young adults were always less likely to have high payment-to-income ratios than middle adults.

Measures of overall debt burdens reflect total amounts owed, but they may obscure the actual month-to-month payment burden faced by young adults. In particular, since student loans may be under deferment (meaning the lender has agreed that payments do not need to be made for a given period of time), the total debt burden may not provide a complete view of the current payment burdens of young adults. Student loan deferments or forbearance can be granted because the borrower is enrolled in school, has financial hardship, is unemployed, or has other reasons for deferment. ${ }^{11}$ The SCF collects information about the deferment status of student loans, so we can separate payment burdens for student loans in repayment, hypothetical burdens of student loans under deferment, and all other debt payments. Figure 9D displays payment-to-income ratios from 2001 to 2013. Each portion of the bar represents the contribution of one type of debt to the overall average payment-to-income ratio for young adults. On average, payments on debt other than student loans represented 17 percent of income in 2001 and fell to 13 percent by 2013. In 2001, student loan payments represented about 5 percent of income; nearly three-quarters of this burden consisted of loans under repayment. By 2013, total student loan payment burdens doubled and reached 10 percent of income. However, about half of this burden consisted of hypothetical payments on loans that were under deferment. Actual student loan payment obligations for loans under repayment were only 5 percent of income, 1-percentage-point higher than in 2001. This indicates that although overall debt burdens had risen for young adults, much of the rise is explained by student loan payments that are not currently a burden to young adult borrowers. If these hypothetical burdens were removed, payment-to-income ratios would have actually fallen for young adults between 2001 and 2013.

Overall, the data present a mixed picture of young adults' experiences with credit markets in 2013 relative to the past and to older adults. Young adults in 2013 experienced higher debtto-income and leverage ratios and were more likely to have late payments than middle adults or young adults in 1989. At the same time, however, young adults in 2013 were less likely to have high payment-to-income ratios than middle adults in 2013, young adults in 2001, or young adults in 1989. Young adults in 2013 were also less likely to report credit constraints than young adults in 2001 or middle adults in 2013.

\section{ARE SCF YOUNG ADULTS REPRESENTATIVE OF ALL YOUNG ADULTS?}

In the Data section, we briefly discussed the SCF sampling frame and how it captures certain types of young adults while missing others. Recall that the SCF does not collect balance sheet information for young adults who are financially independent roommates of a household head or are living with a parent. In this section, we investigate whether this feature of the SCF sampling frame causes the SCF sample to be unrepresentative of the overall young adult population and whether its representativeness has changed over time.

To determine whether the SCF is representative of the population of young adults in the United States, we compare the SCF data with those in sources that are representative at the 


\section{Figure 10}

\section{Percent of Young Adults Living Independently Over Time}

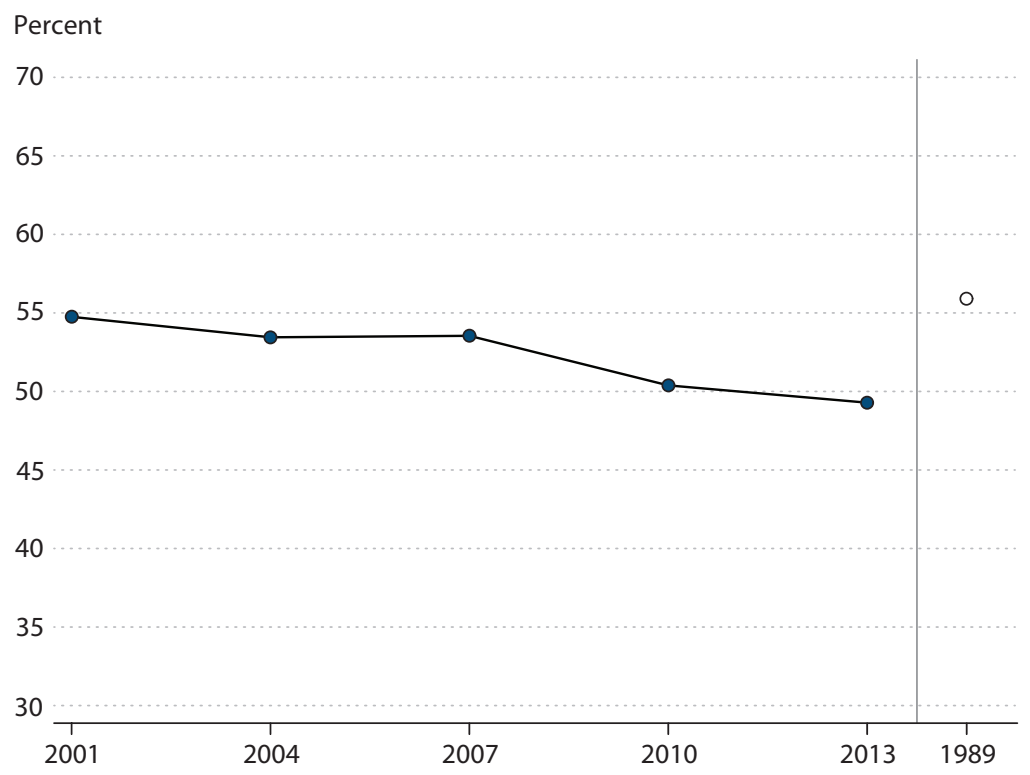

NOTE: The figure shows the trend in the percent of young adults who are living independently (as a household head, spouse, or cohabitating partner). Values are calculated from the March Current Population Survey Annual Social and Economic Supplement in years that correspond to SCF interview years.

SOURCE: CPS.

individual (rather than household) level. Our comparison data source is the March Current Population Survey Annual Social and Economic Supplement (henceforth the CPS). While the CPS does not contain the information on assets or liabilities required for a direct comparison, it does provide information on income, demographics, and living arrangements that can be used to benchmark the SCF data more generally.

We begin by tabulating the fraction of young adults 18 to 31 years of age in the CPS who are living independently (that is, household heads, spouses, or cohabitating partners), which is comparable to the group of young adults observed in the SCF. Figure 10 displays the results of this analysis for SCF survey years 1989 (right side of the figure) and between 2001 and 2013. Over the period studied, young adults were increasingly unlikely to live independently and thus to be a member of the SCF sample. This suggests that the SCF may have become increasingly unrepresentative of all young adult individuals over the past decade.

It is not clear ex ante whether the growing fraction of young adults in living arrangements for which their income and balance sheet information is not captured in the SCF biases the results. If the wealth and income of the young adults not captured by the SCF sampling frame are similar to those of young adults captured by the SCF, then an analysis based on SCF data will provide results similar to a hypothetical study of the overall young adult population. To 


\section{Dettling and Hsu}

examine whether this might be the case, we begin by comparing median wage and salary income tabulated in the CPS with median wage and salary income tabulated in the SCF. ${ }^{12}$ Figure 11A displays median wage incomes for all young adults in the CPS and for young adults for whom wage income information is available in the SCF (household heads and spouses/cohabitating partners). Several observations emerge. First, both CPS and SCF wage and salary income fell between 2001 and 2013. Second, SCF median income was approximately $\$ 10,000$ greater than the CPS median income throughout the period studied. This suggests that young adults who do not live independently tend to have lower wage and salary income than those who do, which raises concerns about the representativeness of the SCF for the overall population of young adults.

Figure 11 shows how SCF and CPS wage income and homeownership rates have evolved. Figure 11B shows the ratio of SCF income to CPS income over time. SCF median wage and salary income between 2001 and 2013 declined less than CPS median wage and salary income. In 2001, median wage income for SCF young adults was approximately 1.6 times larger than median wage income for CPS young adults, rising to approximately twice as large by 2013. Combining these findings with the results shown in Figure 10, which indicate the propensity to live independently declined over this period, further supports the notion that those who live independently tend to have higher incomes than those who do not.

Both data sources also collect information about one asset: homes. Figure 11C displays trends in homeownership rates calculated from the SCF and CPS samples. Not surprisingly, homeownership among the SCF sample was considerably higher throughout the period, since the SCF sample includes only young adults who live independently, while the CPS includes all young adults. Figure 11D displays the ratio of the SCF homeownership rate to the CPS homeownership rate and shows that the ratio has been fairly stable over time. This implies that the decline in the fraction of young adults living independently (and hence the decline in young adults in the SCF sample) has done little to change the homeownership rate in the SCF. We interpret this as evidence suggesting that the marginal young adults not living independently might have been renters, not owners, if they were to live independently.

Overall, our comparison between SCF and CPS data indicates that young adults captured by the SCF tend to have higher incomes and higher homeownership rates than the overall population of young adults in the CPS. Moreover, because fewer young adults lived independently in 2013 than in 2001, SCF median income declined slightly less than CPS median income over the period. If higher incomes are correlated with greater wealth, the SCF will tend to overstate young adults' balance sheets on average. Thus, the results presented in this article should be considered with the caveat that they are representative of only young adults living independently. More broadly, our comparisons with CPS data indicate that SCF users should exercise caution when drawing inferences regarding balance sheet items that are primarily held by young people. 


\section{Figure 11}

\section{Comparison of SCF and CPS Wage Income and Homeownership Rates}

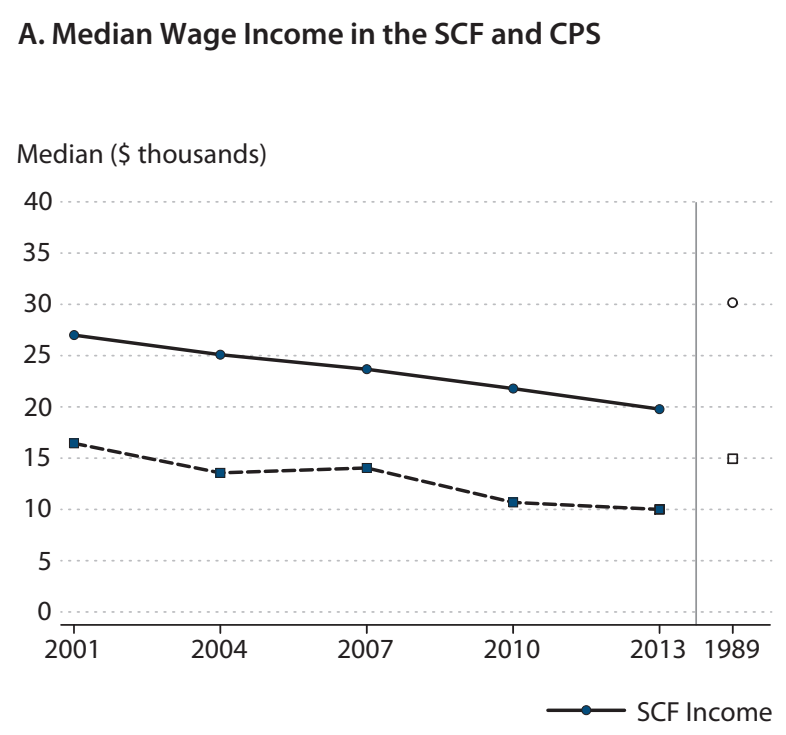

C. Homeownership in the SCF and CPS

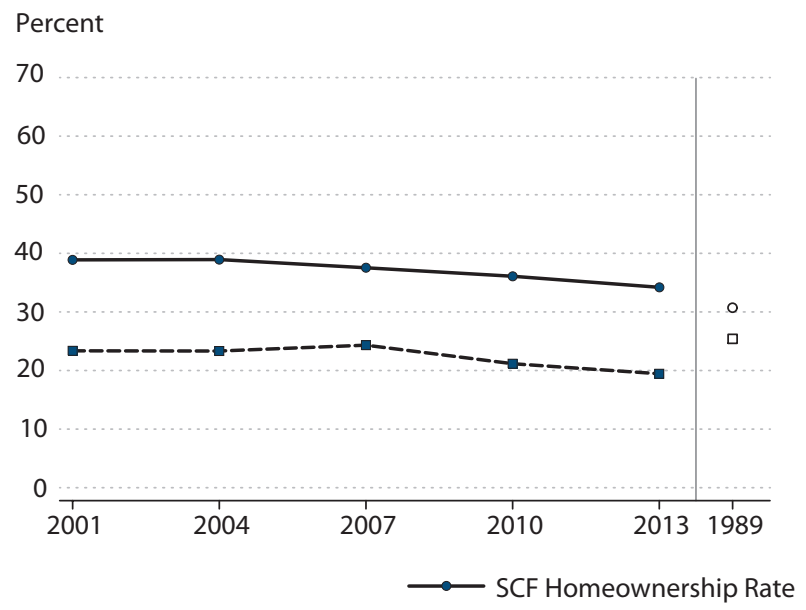

\section{B. Ratio of Median Wage Income}

Ratio of SCF to CPS Median Wage Incomes

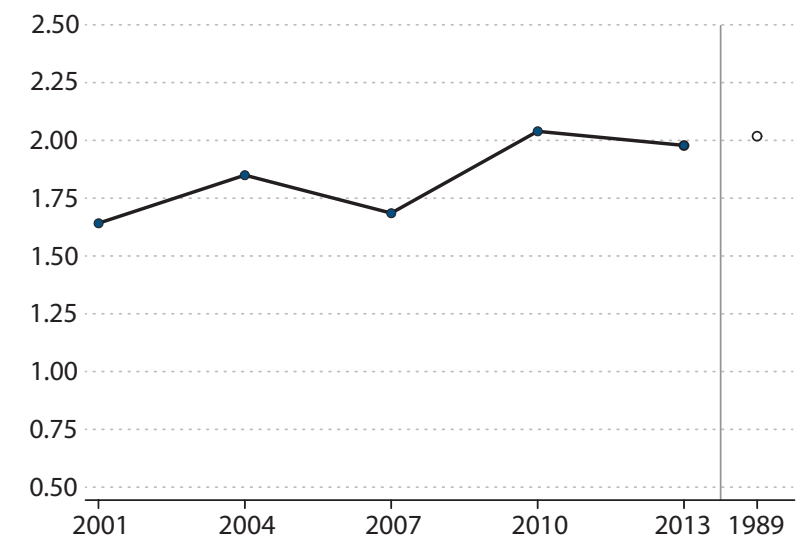

--1--- CPS Income

\section{Ratio of Homeownership Rates}

Ratio of SCF to CPS Homeownership Rates

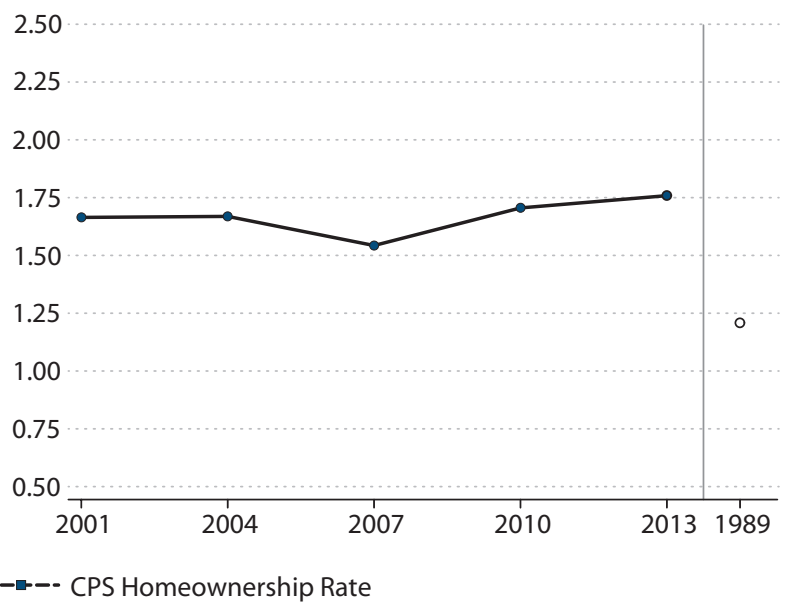

NOTE: The figure shows trends in median wage income (Panel A) and homeownership rates (Panel B) for young adults 18 to 31 years of age in the SCF and CPS. Panels B and D display the ratios. All nominal values were adjusted to 2013 dollars using the CPI-U.

SOURCE: SCF and CPS. 


\section{Dettling and Hsu}

\section{CONCLUSION}

This article examines the state of young adults' balance sheets between 2001 and 2013. We draw comparisons between young adults over time, between young adults and middle adults, and between young adults today in 2013 (members of the "Millennial Generation") and young adults in 1989 (members of "Generation X"). We find that net worth for young adults fell between 2001 and 2013, primarily because of a decline in asset holdings. However, compared with middle adults, young adults experienced a relatively modest decline in net worth, particular during the Great Recession and recovery between 2007 and 2013.

We find that asset holdings among young adults were relatively stable throughout the 2000s, although bank deposits grew slightly and stock holdings, retirement account ownership, and homeownership fell. Yet, relative to young adults in 1989, young adults in 2013 were more likely to own all four of these assets. We find that overall, liabilities declined modestly for young adults over the 2001-13 period with one important exception: student loans, which rose substantially over the period. Much of the increase in student loan balances is driven by increases at the top of the distribution. Compared with young adults from in 1989, young adults in 2013 were more likely to carry student loan debt and less likely to carry credit card, auto, and housing debt. Given that median total debt was no higher in 2013 than 2001, this finding suggests that for young adults, these different forms of debt may be substitutes for one another.

We also examine young adults' experiences with credit markets. We find that young adults in 2013 experienced higher debt-to-income and leverage ratios and were more likely to be late on payments than older adults in 2013 or young adults in in 1989. At the same time, however, young adults in 2013 were less likely to have very high payment-to-income ratios than older adults in 2013, young adults in 2001, or young adults in 1989. Young adults in 2013 were also less likely to report being credit constrained than young adults in 2001 or middle adults in 2013.

Our analysis of SCF data indicates that although the income and net worth of young adults fell between 2001 and 2013, on many measures young adults in the SCF have weathered the Great Recession relatively well compared with both older adults and an earlier cohort of young adults. However, because the SCF can describe only the balance sheets of young adults living independently, the financial circumstances of young adults in the SCF could be better than those experienced by the overall population of young adults. 


\section{NOTES}

1 Young adults in the 2013 survey were born between 1982 and 1995, and young adults from the 1989 survey were born between 1958 and 1971. The Millennial Generation typically encompasses cohorts born between 1982 and 2004, and Generation X typically encompasses cohorts born between 1961 and 1981 (Strauss and Howe, 1997). Thus, young adults from the 2013 survey are a subset of the Millennial Generation and young adults from the 1989 survey consist mainly of members of Generation X.

2 In the SCF, living independently is defined as living as a household head, spouse, or cohabitating partner. This issue is discussed extensively in this section and the section entitled "Trends in Young Adults' Balance Sheets."

3 More information about the SCF, see "Research Resources: Survey of Consumer Finances" (http://www.federalreserve.gov/econresdata/scf/scfindex.htm).

4 The SCF does collect some limited information on income and liabilities for household members who are not financially dependent on the household head. Because of these data limitations, we do not use this information in our analysis.

5 For more information on the components of net worth and their definitions, see Bricker et al. (2014).

6 Our measure of stock ownership includes both stocks within and outside retirement accounts, pooled investment funds, and managed accounts.

7 In 1989, 17 percent of young adults had a defined benefit plan. That number fell to 11 percent by 2013.

8 This measure is generally zero for those who paid their last balance in full. In contrast, measures from credit reports reflect the current balance.

9 Note that vehicle ownership among young adults rose from about 78 percent in 2001 to 85 percent in 2007 and then declined to 82 percent in 2013.

${ }^{10}$ It is beyond the scope of our analysis to determine whether these trends are driven more by demand-side or supply-side factors.

${ }^{11}$ For more information on federal student loan deferment, see https://studentaid.ed.gov/repay-loans/defermentforbearance. Deferment policies for private student loans are lender specific.

${ }^{12}$ We focus exclusively on wage and salary income in this analysis, but the results for total income are similar.

\section{REFERENCES}

Bricker, Jesse; Dettling, Lisa J.; Henriques, Alice; Hsu, Joanne W.; Moore, Kevin B.; Sabelhaus, John; Thompson, Jeffrey and Windle, Richard A. "Changes in U.S. Family Finances from 2010 to 2013: Evidence from the Survey of Consumer Finances." Federal Reserve Bulletin, September 2014, 100(4); http://www.federalreserve.gov/pubs/bulletin/2014/pdf/scf14.pdf.

Debbaut, Peter; Ghent, Andra and Kudlyak, Marianna. "Are Young Borrowers Bad Borrowers?" Working Paper No. 13-09R, Federal Reserve Bank of Richmond, July 13, 2013; http://www.richmondfed.org/publications/research/working_papers/2013/pdf/wp13-09.pdf.

Dettling, Lisa J. and Joanne W. Hsu. "Returning to the Nest: Debt and Parental Co-Residence among Young Adults." Finance and Economics Discussion Papers 2014-80. Board of Governors of the Federal Reserve System, 2014; http://www.federalreserve.gov/econresdata/feds/2014/files/201480pap.pdf.

Fry, Richard. "A Rising Share of Young Adults Live in Their Parent's Home: A Record 21.6 Million in 2012." Social and Demographic Trends. Washington, DC: Pew Research Center, August 1, 2013; http://www.pewsocialtrends.org/2013/08/01/a-rising-share-of-young-adults-live-in-their-parents-home/.

Parker, Kim. "The Boomerang Generation: Feeling OK about Living with Mom and Dad." Social and Demographic Trends. Washington, DC: Pew Research Center, March 15, 2013; http://www.pewsocialtrends.org/2012/03/15/the-boomerang-generation/. 


\section{Dettling and Hsu}

Steuerle, Eugene; McKernan, Signe-Mary; Ratcliffe, Caroline and Zhang, Sisi. "Lost Generations? Wealth Building among Young Americans." Washington, DC: Urban Institute, March 2013;

http://www.urban.org/uploadedpdf/412766-lost-generations-wealth-building-among-young-americans.pdf.

Strauss, William and Neil Howe. The Fourth Turning: An American Prophecy, Broadway Books. 1997.

Thompson, Derek. "Adulthood, Delayed: What Has the Recession Done to Millennials?" Atlantic, February 2012; http://www.theatlantic.com/business/archive/2012/02/adulthood-delayed-what-has-the-recession-done-to-millennials/252913/. 